\title{
506 感温液晶を用いた温度計測法の精度向上に関する研究 Improvement of the Accuracy in Temperature Measurement by Liquid Crystal Thermometry
}

\section{○学 加藤 規靖（新潟大工） Nor iyasu KAT0}

\section{正 藤澤 延行（新潟大工） Nobuyuki FUJISAWA}

Ni igata University 8050 Ikarashi2, Ni igata, Japan, 950-2181

\begin{abstract}
The color-change response of thermo-sensitive liquid crystal tracers to viewing angle was studied by rotating the calibration setup under thermal stratification and the calibration error in temperature measurement was examined. The calibration error was found to be small at negative viewing angles in comparison with the positive one, which suggested an improvement of accuracy in temperature measurement.
\end{abstract}

Key Words :Temperature Measurement, Liquid Crystal, Viewing Angle, Calibration, Uncertainty Analysis

\section{1. 緒言}

感温液晶による温度場のフィールド計測技術は工学上重 要であり、液晶の光学的特性や液晶を用いた温度計測結果 が報告されている。しかし、感温液晶の呈色は観測角度の 変化に依存するなどざまざまな問題がある。本研究では観 測角度による色の变化を利用し、温度計測の精度向上を目 的とする。その基礎データとして、さまざまな観測角度に おける色、温度の関係を定量的に明らかにする。

\section{2. 実験装置および方法}

本実験に使用した感温液晶は呈色範囲が $29-35{ }^{\circ} \mathrm{C} の$ カイラルネマティック液晶であり、平均粒径が $10 \mu \mathrm{m}$ の マイクロカプセル化された液晶粒子が $50 \%$ スラリ一状態 で提供されたものである。この液晶を作動流体である水(水 道水を惹沸したもの）に体積濃度 $0.003 \%$ 加えて実験 した。Fig.1は液晶の光学的特性を計測するために試作した 実験装置である。容器の大きさは $150 \mathrm{~mm} \times 150 \mathrm{~mm} \times 5$ $0 \mathrm{~mm}$ のアクリル製の水槽であり、水槽の上下面をそれぞれ 一定温度に設定することが可能である。本実験では上面を $36{ }^{\circ} \mathrm{C}$ 、下面を $28.5{ }^{\circ} \mathrm{C}$ 設定し、水槽内部に温度勾配一 定の温度成層を作り、検定に用いた。温度成層内の温度分 布の評価は、6 本のK型熱電対を挿入して行った。一方、水 槽側面に設置されたストロボ発光装置からのシート光（厚 さ3 mm) を照射することで液晶の色変化を観察することが できる。ただし観測はカラーC C.Dカメラ（画像解像度 7 $68 \times 494$ ピクセル、RGB信号に対して各 8 ビット)で 行った。ここで、ライトシートに対するカメラの観測角度 $\theta$ の影響を考察するため、ターンテーブル上に水槽とライ トシートを固定し、微小な一定角速度で回転させた。この とき固定されたカメラからは種々の観測角度における液晶 の色と温度の関係を撮影することが可能である。ただし、 ターンテーブルはステッピングモーターで駆動されており、 各画像ごとの観測角度はステッピングモーターのパルス数 から計算できる。本実験では 1 フレーム/秒でカラー画像 を取得したが、この条件は観測角度 $3^{\circ}$ ごとに液晶の色と 温度の関係を検定したことになる。観測角度の範囲はー4 $5^{\circ}$ から+30。で、撮影開始点に設置されたフォトセン サ一からのトリガ入力を合図に撮影を開始する。撮影距離 は $1.7 \mathrm{~m}$ で撮影範囲は $\Delta \mathrm{x} \Delta \mathrm{z}=1.00 \mathrm{~mm} \times 75 \mathrm{~mm}$ の領 域である。撮影された検定画像は、リアルタイムでフレー ムグラバでディジタル化され（640×480ピクセル、R G B に対し各 8 ビット) PC内のフレームメモリに格納さ れる。格納されたR G B カラー画像は、コンピュータ内で ソフト的にHS I 色空間に変換して検定画像とした。

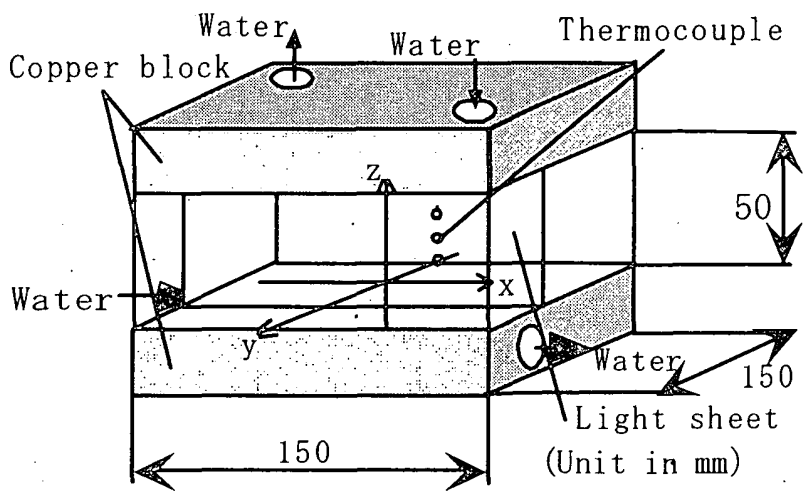

Fig. 1 Test section

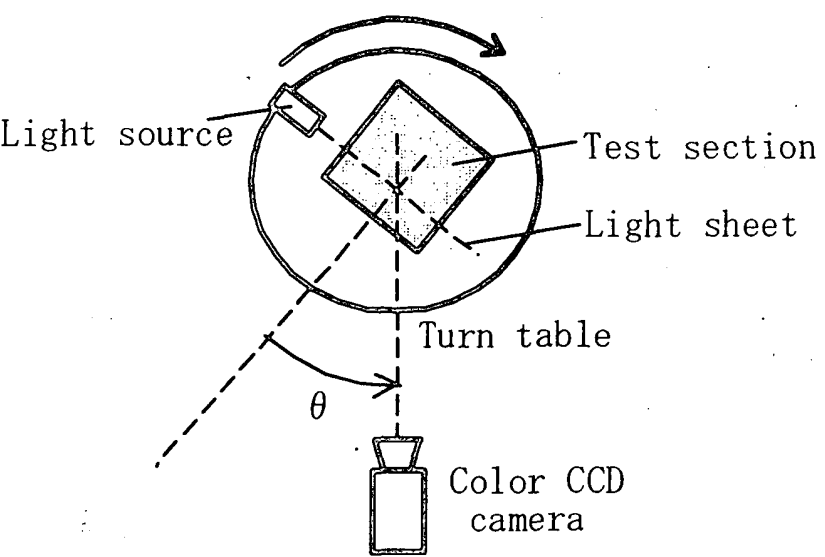

Fig.2 Top view experimental setup

\section{3. 結果および考察}

\section{1 温度成層評価}

Fig. 3 は温度成層の位置と温度および加熱時間の関係を 表している。上下壁面温度が一定であるため、温度勾配は 時間と共に直線へと変化し定常状態となった。ただし、本 実験装置の場合、定常状態になるまでの時間は約 90 分を 要した。このとき測定温度と直線的温度分布との相違は 0 . $1{ }^{\circ} \mathrm{C}$ 以下であり、それは熱電対の測定誤差と同程度であっ た。 


\section{2 鲵測角度によるH S I変化}

Fig. 4 は本実験における一例として、測定温度 (Tm) と ヒュー(H)、サチュレーション $(\mathrm{S}) 、$ インテンティ(I)それ ぞれの值との関係を、観測角度-450 $5^{\circ}-30^{\circ}-15^{\circ}$ $0^{\circ} 15^{\circ} 30^{\circ}$ についてそれぞれプロットした図である。 ヒューの温度による変化を見ると、観測角度が大きくなる ほど温度変化に伴うヒューの変化が大きい。すなわち観測 角度 $0^{\circ}$ の場合に比して観測角度一 $45^{\circ}$ のときは、かな り広い温度域でヒューの温度による変化量が大きいため測 定精度の向上が期待できる。サチュレーションの関係にお いて、観測角度一 $45^{\circ}$ の場合 $34^{\circ} \mathrm{C}$ を越える温度帯域に おける $\mathrm{S}$ の変化がほとんど見られないのに対して $0^{\circ}$ では 同温度帯域におけるSの変化が見られる。インテンシティに 関しては観測角度の違いで値の違いはあるものの、I の変 化量については大きな違いは見られなかった。温度検定を 行うにあたっては、これら各角度におけるHＳＩの変化が 検定に有利に働く点に着目し、さまざまな組み合わせを行 うことで従来の温度検定法よりもより高精度な温度検定が 期待できる。

\section{3 誤差の評価}

感温液晶スプライン温度検定法によって各ピクセルごと の温度を推定し、等温方向すなわち $\mathrm{x}$ 方向についての標準 偏差を求めた (Fig. 5 )。誤差が最も小さく安定した呈色を 示しているのは観測角度一 $45^{\circ}$ のときである。一方、正 方向の観測角度は誤差が大きくなっている。低温帯域では 誤差が小さく高温帯域では誤差が大きい。これは高温域で のHS I の変化量が少ないためであると言える。すなわち、 温度変化にH S I 各成分が敏感に反応する温度带域が誤差 の少ない優良な検定区間になりうるといえる。

\section{4. 結言}

さまざまな観察角度におけるヒュー、サチュレーション、 インテンシティ変化を定量的にあきらかにした。その結果、 負の観測角度において比較的良好な温度計測精度が得られ た。

\section{参考文献}

(1) 船谷俊平、藤沢延行、松浦勉、弦巻明、機論、66-643, B (2000-3) 、121-127.

(2) N.Fujisawa and S. Funatani,Exp.Fluids, 29 (2000) in press.

（3）亀井泰造、笠木伸英、可視化情報、vol14. suppl. nol (1994), 89-92.

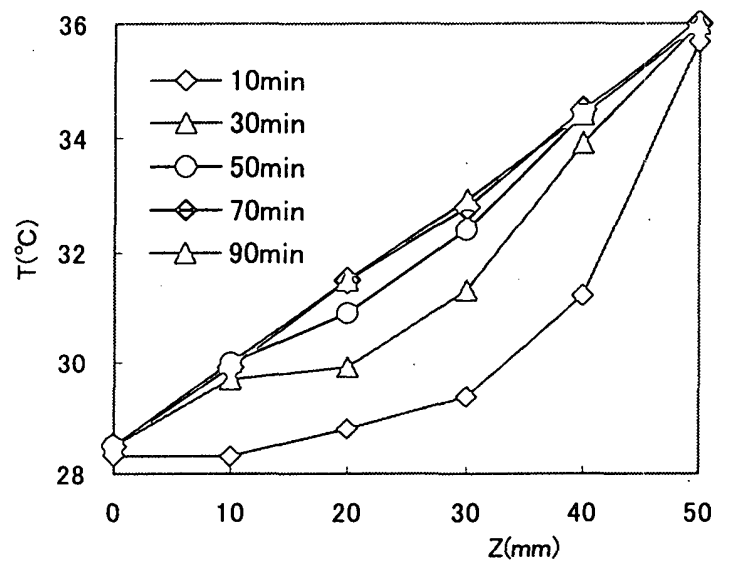

Fig.3 Temperature profile
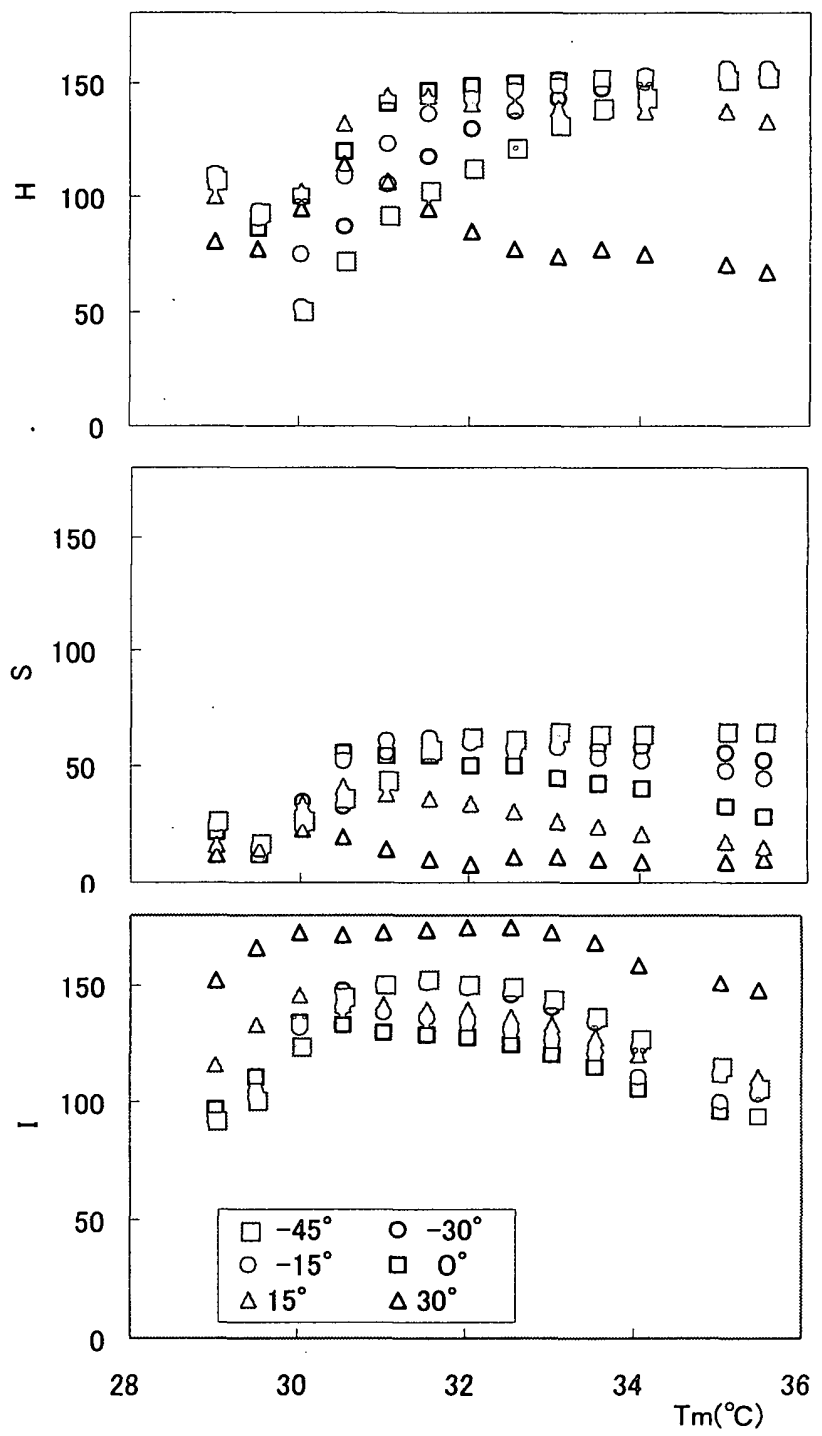

Fig.4 Optical characteristics of liquid crystal for various viewing angles

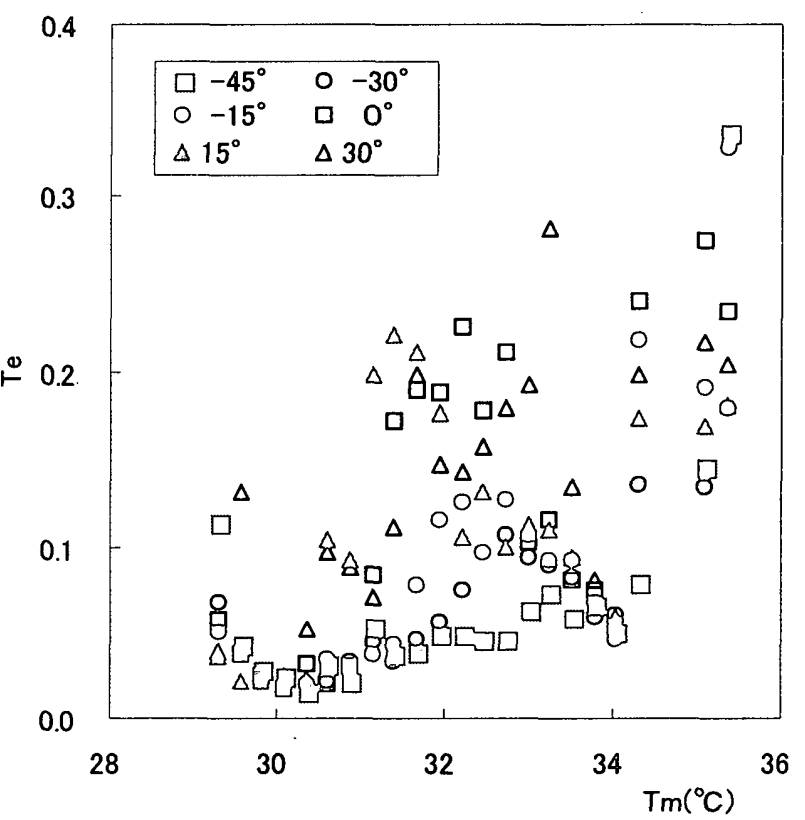

Fig. 5 Calibration error Te versus temprature Tm for various viewing angles 